\title{
Indian Labour Immigration and British Labour Policy in Nineteenth-Century Ceylon
}

\author{
ROLAND WENZLHUEMER
}

Centre for British Studies, Humboldt-Universitaet zu Berlin

\begin{abstract}
During most of the nineteenth century, the economy of the British crown colony Ceylon depended almost exclusively on the export of plantation products. After modest beginnings in the 1820 s and 1830 s, coffee cultivation spread on the island in the 1840 os. During the 1880 s, the coffee plantations were superseded by plantations of a new crop-tea. Both cultivation systems were almost pure export monocultures, and both relied almost exclusively on imported wage labour from South India. Thus, it is surprising that labour immigration-a process vital to the efficient functioning of the plantation economy-received practically no government attention for the better part of the nineteenth century. Migration between South India and Ceylon was free of government control, support or regulation. Instead, certain functional equivalents-such as the kangany system-organised immigration and coordinated supply and demand. Only very late in the century, when the kangany system had revealed a number of dramatic organisational weaknesses, the Ceylon Government started to get directly involved in labour and immigration policy.
\end{abstract}

The author can be contacted at roland.wenzlhuemer@staff.hu-berlin.de

\section{An Agricultural Export Economy}

With the conquest of the inland kingdom of Kandy in the year 1815 the British did not only politically unify the island of Ceylon (today's Sri Lanka) for the first time since about 600 years-they also brought under their control the island's region with the highest economic potential. Their Portuguese and Dutch predecessors had extracted economic profit from their coastal holdings (their most notable venture being the export of cinnamon), but they had lacked suitable lands to open large-scale cash crop plantations in higher altitudes. Dutch attempts to introduce large-scale coffee planting to the island failed due to the lack of suitable mid-country or up-country lands. On the other hand, those with access to such lands-namely the Kandyan peasantry-already produced small amounts of coffee oo26-749X/o7/\$7.50+\$0.10 
on their own relying mainly on the wild-growing coffee berries. Most of the exported coffee up to the early 1830 -around 10.000 cwt. annually — was of such peasant origin. ${ }^{1}$

When the Ceylon Government began with the construction of a road from the coastal capital of Colombo to Kandy, it primarily aimed at bringing the Kandyans under closer control of the colonial power after the so-called Kandyan rebellion of 1818 . However, with the opening of the road in 1820 , they also started to economically develop the Sri Lankan highlands. The hitherto difficult-to-reach Kandyan highlands were infrastructurally connected to a slowly emerging transport network and, accordingly, to the commercial centres of the coast. The Colombo-Kandy road thus served at least two different ends crucial to an economically favourable environment: it a) opened up suitable plantation lands and b) provided for the security of potential investments. With plantation land readily available, local capital was soon attracted to the region. During the 1820 s, coffee plantations started to serve as a capital outlet mainly for local Government officials. Governor Edward Barnes, for instance, granted land near Gampola to Colonel George Bird in 1823-24. Barnes himself also participated in coffee cultivation in the 1820 s and several others established plantations as well. However, according to Michael Roberts, most of these early ventures remained economically unsuccessful. ${ }^{2}$ Reasons for this can be found in the use of not fully suitable land in too low altitudes, the unfavourable position of Ceylonese coffee in the world economy-with the West Indies as a formidable competitor-and the lack of coffee cultivating skills.

During the 183os, the national and international economic background concerning the cultivation of coffee changed profoundly. In Ceylon, the Cameron-Colebrooke reforms of 1833 abolished the cinnamon monopoly inherited from the Dutch and liberalised the cinnamon trade. ${ }^{3}$ This placed Ceylonese cinnamon at a disadvantageous position in the world market and practically killed cinnamon cultivation on the island thereby creating demand for a

${ }^{1}$ M. Roberts and L. A. Wickremeratne, 'Export Agriculture in the Nineteenth Century', in K. M. De Silva (ed.), University of Ceylon History of Ceylon. From the Beginning of the Nineteenth Century to 1948 (Peradeniya: University of Peradeniya, 1973), p. 92.

${ }^{2}$ Ibid., p. 94 .

${ }^{3}$ For a more detailed description of the cinnamon trade in the early nineteenth century see: V. Samaraweera, "Economic and social developments under the British, 1796-1832", in K. M. De Silva (ed.), University of Ceylon History of Ceylon. From the Beginning of the Nineteenth Century to I948 (Peradeniya: University of Peradeniya, 1973). 
TABLE 1

The Ceylon Coffee Industry, I834-69 (Annual Figures and Annual Averages)

\begin{tabular}{lllll}
\hline Year & $\begin{array}{l}\text { Export volume } \\
\text { (in ooo cwt.) }\end{array}$ & $\begin{array}{l}\text { Export unit } \\
\text { value (in s./cwt.) }\end{array}$ & $\begin{array}{l}\text { Area planted } \\
\text { (in ooo acres) }\end{array}$ & $\begin{array}{l}\text { Yield (in } \\
\text { cwt./acre) }\end{array}$ \\
\hline 1834 & 26 & 30 & $\mathrm{n} / \mathrm{a}$ & $\mathrm{n} / \mathrm{a}$ \\
$1835^{-39}$ & $4^{6}$ & 47 & $\mathrm{n} / \mathrm{a}$ & $\mathrm{n} / \mathrm{a}$ \\
$184^{0}-44$ & 97 & 49 & 23 & $4 \cdot 2$ \\
$1845^{-49}$ & 260 & 33 & $5^{1}$ & $5 \cdot 1$ \\
$185^{0}-54$ & 344 & 40 & 59 & $5 \cdot 9$ \\
$1855^{-59}$ & 537 & $4^{8}$ & $13^{8}$ & $3 \cdot 9$ \\
$1860-64$ & 615 & $5^{1}$ & 199 & $3 \cdot 1$ \\
$1865^{-69}$ & 939 & $5^{2}$ & 243 & $3 \cdot 9$ \\
\hline
\end{tabular}

Source: Snodgrass (1966): 20.

different cash crop. Meanwhile at the other end of the British Empire, the West Indian coffee producers faced a severe crisis. The British Government not only abolished slavery and thus deprived the West Indian plantations of their cheap and reliable labour supply, it also fixed the custom duty for both West Indian and Ceylonese coffee at $6 \mathrm{~d}$. per pound ${ }^{4}$ and discontinued its protective policy towards the West Indian coffee trade. The consequent crisis of West Indian coffee cultivation placed the Ceylonese plantations at an excellent position in the world market. At the same time, tropical agriculturists introduced Caribbean coffee growing skills to the island and improved the methods employed in the planting and processing of coffee. Combined, these factors triggered the rush into coffee cultivation that Ceylon witnessed in the 1830 and during the 'coffee-mania' of the 1840 os.

Table 1 has been adapted from Donald Snodgrass' important but meanwhile out-of-date work $^{6}$ on Ceylon's agricultural export economy. The figures rely on official sources and, thus, are incomplete and only half-accurate at times. Nevertheless, they illustrate the rapid expansion of coffee cultivation and export in Ceylon from the 183 os onwards. Favourable world market conditions, developing infrastructure and incredibly cheap plantation land had turned coffee

${ }^{4}$ A. Bandarage, Colonialism in Sri Lanka: The Political Economy of the Kandyan Highlands, I833-1886, vol. 39, New Babylon, Studies in the Social Sciences (Berlin, New York: Mouton, 1983), p. 72 .

${ }^{5}$ This is not the actual average yield per acre. Snodgrass simply divided the export volume of coffee by the total area under the crop-areas in bearing as well as newly planted areas.

${ }^{6}$ D. R. Snodgrass, Ceylon; an Export Economy in Transition (Homewood, Illinois.: R. D. Irwin, 1966). 
cultivation into a highly profitable business during the 1830 o. Planters and capital from the homeland soon started to pour into the colony and furthered the expansion of the plantation economy. ${ }^{7}$ During the so-called 'coffee-mania' of the 1840 , Ceylon's economy was restructured as a plantation-based agricultural export economy, and coffee monoculture firmly established for the next forty years.

\section{Local Labour Shortage}

In his seminal work on tropical agriculture, W. A. Lewis identifies four 'preconditions for agricultural exports' additional to the standard factors of production land, labour and capital: internal peace, water, transportation and economies of scale. ${ }^{8}$ In the case of Ceylon's emerging coffee export economy, most of these preconditions were easily fulfilled: with the opening of the Kandyan highlands, suitable plantation land was readily and cheaply available; the favourable world market conditions attracted large amounts of capital to the island and facilitated the rise of banks and agency-houses in Ceylon; internal peace and transportation were secured by the Ceylon Government's investments in road construction and communications development; rich in rainfall the Kandyan highlands initially offered enough water for both peasant and plantation agriculture $;^{9}$ and economies of scale only became relevant in Ceylon with the transition from coffee to tea cultivation during the 188 os.

Only the supply of the emerging plantation sector with a steady and reliable labour force could apparently not be guaranteed with only local resources at hand. In the early nineteenth century the forestcovered central highlands of Ceylon were relatively sparsely populated. Pressure on land was practically unknown until the tremendous expansion of coffee plantations in the 185 os and 1860 . The Kandyan peasantry in the highlands made a living from paddy cultivation,

${ }^{7}$ I. H. Vanden Driesen, "Some aspects of the financing of commercial enterprise in 19th century Ceylon", Ceylon University Review, vol. 18, no. 3+4 (1960), 215 . I. H. Vanden Driesen, "Some trends in the economic history of ceylon in the 'Modern' Period", Ceylon Journal of Historical and Social Studies, vol. 3, no. 1 (1960), 13.

${ }^{8}$ W. A. Lewis, "The export stimulus", in W. Arthur Lewis (ed.), Tropical Development, I880-1913 (Evanston: Northwestern University Press, 1970), p. 16.

${ }^{9}$ Later in the nineteenth century, clean water became a rarer commodity in the highlands, as the ever-expanding plantations in higher altitudes started to cut into the water supply of the village paddy fields. See: J. L. A. Webb, Tropical Pioneers: Human Agency and Ecological Change in the Highlands of Sri Lanka, I 80o- I9oo, Ohio University Press Series in Ecology and History (Athens, Ohio: Ohio University Press, 2002), pp. 87-88. 
shifting cultivation and from small coffee gardens of their own. Landlessness was not widespread and those who did not own land themselves usually worked as sharecroppers. As Wickramasinghe and Cameron put it, '[n]ot land but labour was scarce." ${ }^{10}$ Taxation in those early decades of the nineteenth century remained rather light and payable either in cash or kind. ${ }^{11}$ The so-called cash nexus had not yet reached the peasant communities of the highlands and accordingly the peasantry's demand for ready cash was limited and could mostly be satisfied from their small-scale trade in coffee.

Taken together these were not very promising circumstances as regards the creation of a permanent wage labour force for the plantations. In the days of coffee cultivation, the Kandyan peasants simply did not experience enough economic pressure to be pushed into plantation wage labour in any significant numbers. Although Sinhalese peasants frequently entered into contracts with the planters and mainly cleared forest land for future plantations, these assignments were mostly of a temporary nature and for a fixed task only. Regarding the Sinhalese contribution to regular estate wage labour during the early years of coffee cultivation, little has been researched and written on this topic-and when we find clear statements on that topic, scholarly opinions diverge. While it seems to be a widespread view among economic historians of nineteenth-century Ceylon that the first coffee planters of the 1820 s and 1830 os employed Sinhalese wage labour as well, relied largely on Sinhalese labour or at least desperately tried to recruit local Sinhalese labour, this view has recently been challenged by Patrick Peebles in 'The Plantation Tamils of Ceylon'. Peebles says that 'there is little evidence that planters attempted and failed to hire a Sinhalese plantation labor force. There are few references by planters in the I 840 s to Sinhalese laborers except to praise their skill at felling jungle'. ${ }^{12}$ Although Peebles has been overly keen throughout the entire book to re-write the history of the plantation Tamils and is often not able to present convincing evidence for his views, he might have a point when he doubts the coffee planters' dedication to obtaining a labour force locally. In Peebles' opinion the myth of

${ }^{10}$ D. W. A. Wickramasinghe and D. C. Cameron, "British Capital, Ceylonese Land, Indian Labour: The Imperialism and Colonialism of Evolution of Tea Plantations in Sri Lanka". (Paper presented at the Critical Management Studies Conference (Management and Organizational History), Cambridge, 4-6 July 2005).

${ }^{11}$ D. Wesumperuma, Indian Immigrant Plantation Workers in Sri Lanka: A Historical Perspective, I880- I9Io. (Nugegoda: Dharmapriya Wesumperuma, 1986), p. 11.

${ }^{12}$ P. Peebles, The Plantation Tamils of Ceylon, New Historical Perspectives on Migration (London, New York: Leicester University Press, 2001), p. 30. 
the Sinhalese peasants' reluctance to take up wage labour has mainly been a British construction of later days to justify the 'import' of Indian labourers. ${ }^{13}$ With only rare references to the composition of the early coffee labour force, it remains difficult to establish the Sinhalese contribution to estate wage labour in the 1820 and 1830 . As cited by Peebles, ${ }^{14}$ Boyd refers to Sinhalese labourers working under Sinhalese foremen on plantations in the year 1838 . Later, the planter Frederick Lewis describes the workforce employed on his estate as largely of Sinhalese origin. ${ }^{15}$ And, as I have pointed out elsewhere, the late 1880 s and 1890 s see a rush of impoverished Sinhalese villagers into plantation wage labour. ${ }^{16}$ This generally supports the notion that a certain number of Sinhalese villagers have always sold their work to the estates-presumably mostly those who lived in the vicinity of the plantations and were able to return to their villages every evening. ${ }^{17}$ We will probably never be able to give anything like an accurate number of Sinhalese working on the estates in the 1820 s and 183 os. However, it is reasonable to suggest that only a comparatively small number of Sinhalese villagers have done so, when we consider the missing economic pressure and the frequent ill-treatment of the workers by estate superintendents. ${ }^{18}$

Considering all the evidence we have at this point, it seems only reasonable to assume that the planters indeed have not tried to recruit local Sinhalese labour particularly desperately. On the one hand, a certain portion of Sinhalese villagers was not at all adverse to estate wage labour, as we have seen above. And the labour demand of the earliest plantations has been manageable. On the other hand, there have already been around 10,0oo immigrant labourers in Ceylon in the 1820 s and $1830{ }^{19}$ looking for work in road construction, the

${ }^{13}$ Ibid.

${ }^{14}$ Ibid.

${ }^{15}$ F. Lewis, Sixty-Four Years in Ceylon: Reminiscences of Life and Adventure (Colombo: Colombo Apothecaries, 1926), pp. 191-92.

${ }^{16}$ R. Wenzlhuemer, "The Sinhalese contribution to estate labour in Ceylon, 18811891 ", Journal of the Economic and Social History of the Orient, vol. 48, no. 3 (2005).

${ }^{17}$ See F. Heidemann, Kanganies in Sri Lanka and Malaysia: Tamil Recruiter-CumForeman as a Sociological Category in the Nineteenth and Twentieth Century, Ganesha; 5 (Muenchen: Anacon, 1992), p. 11.

${ }^{18}$ M. Roberts, "Indian estate labour in Ceylon during the coffee period (18301880). Part 1", Indian Economic and Social History Review, vol. 3, no. 1 (1966), 1.

${ }^{19}$ Heidemann, Kanganies in Sri Lanka and Malaysia, 11. N. Kuruppu, "A history of the working-class movement in Ceylon. 1. Labour and the rise of capitalism", Ceylon Historical Journal, vol. 1, no. 2 (1951), 134. 
upkeep of irrigation facilities or as agricultural labourers. With such a plentiful, willing and cheap labour supply at hand, it seems doubtful that the coffee planters have spent more time and effort on the recruitment of Sinhalese villagers than was absolutely necessary. At the same time, it becomes unlikely that the abolition of rajakariya labour (corvee labour) by the Cameron-Colebrooke reforms of 1833 really aimed at the creation of a wage labour market, as it has often been pointed out. ${ }^{20}$

\section{Indian Labour Migration}

So, although local Sinhalese villagers participated in plantation wage labour in those early coffee years, the planters soon tapped a different source of cheap labour. Agricultural wage labourers from the densely populated regions of South India were close at hand looking for employment on the neighbouring island of Ceylon. The Ceylon Government had used an immigrant workforce from South India for public works construction since the turn of the century. Favoured by its geographical proximity, the island of Ceylon had early become one of the first outlets for South Indian excess labour. In the 1830 , other British colonies around the globe began to see the potential benefits of South India's well-stocked labour market and started to recruit labour there. In the year 1834 , labour migration from India to most parts of the world was organised along the lines of the infamous indenture system. Only migration to the comparatively close and easyto-reach destinations Ceylon, Malaya and Burma (then officially a part of British India) remained so-called 'free'21 labour migration.

${ }^{20}$ For instance, by Wesumperuma, Indian Immigrant Plantation Workers, 6. Rather, the main intention behind the abolition was a weakening of the powers of the mudaliyars who controlled the rajakariya labour force and abused this power to their own advantage. See P. Peebles, Social Change in Nineteenth Century Ceylon (New Delhi: Navrang in collaboration with Lake House Bookshop, Colombo, 1995), pp. 118-19. Until its abolition rajakariya labour had also been used on the Government officials' own estates. See N. Dawood, Tea and Poverty: Plantations and the Political Economy of Sri Lanka (Kowloon, Hong Kong: Urban Rural Mission, Christian Conference of Asia, $1980)$, p. 43 .

${ }^{21}$ It has become a well-established tradition among historians concerned with this kind of 'free' labour migration to put the word 'free' within inverted commas. As we will see later, the rigorous contracts binding the labourers in the indenture system had several functional equivalents in 'free' labour migration attaching the labourers in more informal but only little less effective ways to their employers. 
In the overpopulated regions of the Madras Presidency landlessness was widespread and droughts and famines occurred frequently. ${ }^{22}$ Satyanarayana shows that labour emigration from South India responded regionally as well as chronologically to crop failures, bad seasons, famines or other environmental calamities. ${ }^{23}$ The number of landless agricultural labourers in the South Indian districtsalready about 10 to $15 \%$ of the total population at the beginning of the nineteenth century-further increased throughout the century. ${ }^{24}$ This was partly due to the 'disintegration of the Indian village handicraft industries consequent on the flooding of the Indian market with cheaper Britishmanufactured articles'. ${ }^{25}$ Many village artisans could not compete with the British producers and had to make a living as agricultural labourers. Furthermore, the ongoing monetisation of village life and the introduction of the cash nexus to the traditional Indian villages drove many small peasant proprietors into indebtedness and, as a consequence, into landlessness, as debtors were often dispossessed of their holdings. ${ }^{26}$ This further increased the number of landless agricultural labourers in search for employment and created a demand for ready cash at a very early date.

Thus, agricultural labourers responded to arising 'job opportunities' outside South India in steadily increasing numbers. By the 1830 , labour emigration from India had increased to such an extent that the Government of India enacted the Indian Emigration Ordinance regulating the terms of Indian labour migration. Employer and employee entered into a three- or five-year contract that fixed mutual rights and duties. Labour recruiters in India had to obtain a license from the government and recruitment as well as the conditions of the labourers in the country of destination became-theoreticallyobserved by the Indian and the 'host' government. Recruitment, transhipment and plantation work were rigidly organised and partially subsidised by the government both to secure a steady supply of labour to the overseas plantations and to guarantee the welfare of the labourers. The thus enacted system of labour recruitment and

${ }^{22}$ O. Hollup, Bonded Labour: Caste and Cultural Identity among Tamil Plantation Workers in Sri Lanka (New Delhi: Sterling Publishers, 1994), p. 26.

${ }^{23}$ Adapa Satyanarayana, Birds of Passage. Migration of South Indian Labour Communities to South-East Asia, I9-2oth Centuries, A.D., Clara Working Paper I I (Amsterdam: 2001), 13 .

${ }^{24}$ D. Wesumperuma, Indian Immigrant Plantation Workers, p. 15.

${ }^{25}$ Ibid., p. 16.

${ }^{26}$ Ibid. 
migration became known as the indenture system. Lax government controls and the pronounced economic interest of the 'hosts' led to frequent abuses of the system and the availability of a cheap and steady workforce soon became much more important than the welfare of the workers. In the year 1834, the first indentured labourers were recruited in India and transhipped to the sugar plantations of Mauritius. However, the living and working conditions of the labourers were so harsh that the Indian Government suspended emigration to Mauritius in 1839 . Only in 1842 the Colonial Office yielded to the planters' pressure and ordered the resumption of indentured migration to Mauritius. ${ }^{27}$ It is little surprising that, accordingly, labour migration under the indenture system soon became known as 'unfree' labour migration and labour historians have frequently referred to it as a 'new system of slavery'. ${ }^{28}$

Labour migration from India to Sri Lanka (as well as Burma and Malaya) was not organised along the lines of the indenture system. Migration in these cases was free of government intervention and the Indian Emigration Ordinance did not cover migration across the Paumben Strait. This policy of the Indian Government might be attributed to a variety of different lines of thought: firstly, Ceylon's location so close to South India made an effective control of migration between the two colonies practically impossible; secondly, labour migration to Ceylon was-at least allegedly-primarily of a merely seasonal (and thus cyclic) character; thirdly, considering the longestablished trade and social links across the Paumben Strait economic push and pull factors seemed sufficient to regulate the flow of migrant labour; fourthly, it was appreciated by the Madras officials to have an outlet for excess agricultural labourers; fifthly, the Ceylon Government had already hired South Indian labour since the turn of the century; and sixthly, the island seemed close enough to keep an eye on the living and working conditions of the labourers anyway. Especially, items one and four seemed to have played a decisive role in the decision-making process.

Thus, migration between South India and Ceylon remained free throughout the nineteenth century. Migrant workers were not subjected to government control and were not bound by indenture-like

27 P. Peebles, The Plantation Tamils of Ceylon, p. 26.

${ }^{28}$ See H. R. Tinker, A New System of Slavery. The Export of Indian Labour Overseas, I830-1920 (London: Oxford University Press, for the Institute of Race Relations, 1974). 
contracts for years. Although the legal possibility to enter into written contracts existed, practically all immigrant labourers had merely verbal contracts with their employers. These contracts had a validity of one month and were automatically extended at the end of each day. Both parties could terminate the engagement at one month's notice. From a legal perspective, this practice rendered the immigrants free wage labourers as they were not bound by year-long work contracts and were free to quit at relatively short notice. With the acreage under coffee rapidly expanding, it soon became obvious that such lenient terms of contract would not especially contribute to the creation of a reliable and steady labour force in Ceylon-even with a seemingly infinite supply of potential wage labourers close at hand in South India. Thus, the labourers were bound to their employers by other means which will be discussed in detail later: restrictive labour laws, debt bondage and marginal balance wages.

\section{Migration to Sri Lanka}

Due to their geographical proximity migration and trade between South India and Ceylon both build on a longstanding history. The history of the island's kingdoms as well as Ceylon's ethnic composition both tell tales of the close relations maintained across the easily traversable Paumben Strait. Although we do not possess any reliable quantitative evidence for this, it is reasonable to suggest that the comparatively sparsely populated island has attracted landless agricultural labourers from South India even before the advent of the British. Therefore, we cannot say whether the early immigrant labourers were actively recruited by Ceylonese planters or the Ceylon Government in their Indian homeland or whether they were simply hired while looking for work in Ceylon on their own initiative. ${ }^{29}$ What

${ }^{29}$ Again, Patrick Peebles challenges a longstanding view (advocated, for instance, by Kingsley De Silva) that even the earliest immigrants were recruited in India. Peebles turns De Silva's argument around and holds that active labour recruitment came into existence only in later coffee planting years. Unfortunately, Peebles does not present any reliable evidence for his notion and, accordingly, his view remains just as plausible as De Silva's. Peebles, The Plantation Tamils of Ceylon, p. 27. Kingsley M. De Silva, "Indian immigration to Ceylon: the first phase C. 1840-1855", Ceylon Journal of Historical and Social Studies, vol. 4 (1961), 110. Kingsley M. De Silva, Social Policy and Missionary Organizations in Ceylon, I $840-1855$ (London: Longmans, 1965), p. 239 . 
we know is that Governor Frederick North in the very first years of the nineteenth century employed a pioneer corps consisting of Indian immigrants. And during the Kandyan rebellion of 1818 Governor Brownrigg relied on 5, ooo Indian workers to make up for the local labour shortage in the wake of the rebellion. Brownrigg's successor Barnes employed Indian labour (together with rajakariya labour) in the construction and upkeep of public works-mostly roads. ${ }^{30}$ Although this does not shed more light on the place of recruitment, it illustrates that the early coffee planters could easily benefit from the existing practice of labour migration from South India when confronted with a local shortage of wage labour. This is even more noteworthy as the earliest coffee estates of the 1820 s served primarily as a field of financial investment for high-ranking Government officials for whom Indian immigrant labour was easily obtainable.

By 1844 the latest, labour recruitment in India became common as the Planters' Association reports that the owner of Black Forest estate sent a recruiter to India in that year who later returned with fourteen workers. ${ }^{31}$ Whether or not this really marks the first occurrence of direct Ceylonese labour recruitment in India, the everrising labour needs during the 'coffee-mania' of the 184 os demanded for a steady influx of agricultural labourers and, thus, for a more thoroughly organised system of labour recruitment. To this demand responded the so-called kanganies. Hitherto these kanganies had simply been persons of some reputation and experience who acted as leadersamong-equals for the immigrating labour gangs. Usually they had already worked on Ceylonese plantations or in construction gangs and now put their experience to use by leading willing labourers to the plantation districts of Ceylon and establishing contact with the planters. During that early phase the kangany was a labourer himself and exerted no or little power over the other labourers who originated largely from the kangany's village or kinship group. ${ }^{32} \mathrm{On}$ the estates, the kanganies served as middlemen between the planters and the workers.

${ }^{30}$ N. Kuruppu, "A history of the working-class movement", p. 134. C. R. De Silva, Ceylon under the British Occupation, I795-1833 (Colombo: Colombo Apothecaries, 1953), p. 405 .

${ }^{31}$ P. Peebles, The Plantation Tamils of Ceylon, p. 27. L. De Mel, The Evolution of Industrial Relations in Ceylon; with Special Reference to Plantations, International Educational Materials Exchange, 3026 (Geneva: International Institute for Labour Studies, 1972), p. 1.

${ }^{32}$ F. Heidemann, Kanganies in Sri Lanka and Malaysia, pp. 12-13. 
This early kangany system-based largely on kinship ties and reputation-soon failed to secure a labour force large enough to satisfy the demand. Therefore, the planters encouraged the kanganies to actively recruit labourers in India. They chose reliable kanganies or experienced workers and sent them to South India to recruit new labourers. With the rapid expansion of the plantation system the demand for immigrant labour rose so quickly that the planters started to give so-called coast advances to the kanganies-advances to finance the recruiter's journey to India as well as the return trip of the future labourers. Additionally, the kanganies started to receive a premium for every recruited labourer that they brought to the

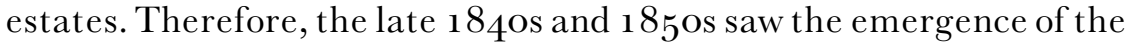
professional kanganies, who did not make a living as estate labourers anymore but earned their money as professional labour recruiters and supervisors. ${ }^{33}$ We will soon see how this newly established recruitment and immigration system started to secure the planters' (and later the kanganies') hold over the immigrant labourers and acted as an effective functional equivalent to the non-existent government efforts towards the organisation of labour immigration.

\section{Early Government Policy, Labour Legislation and Functional Equivalents}

Patrick Peebles holds that up to the year 1839 the Ceylon Government has viewed Indian labour immigration with a critical eye and even opposed it. ${ }^{34}$ Again, the evidence presented to support this notion is scarce and altogether not very convincing-especially given the fact that up to the 183 os the Ceylon Government (along with government officials) has been the chief employer of Indian labour in Ceylon. But what can be safely said is that the Ceylon Government did neither recognise the present and future importance of Indian labour for the Ceylonese economy nor did it actively encourage the influx of Indian labour. Only in 1839 did the government begin to compose statistics on immigration. Furthermore, the Ceylon Government built a causeway to Mannar and established a ferry service between Rameswaram and Mannar, thus facilitating the crossing of the Paumben Strait for

\footnotetext{
${ }^{33}$ Ibid., p. 16.

${ }^{34}$ P. Peebles, The Plantation Tamils of Ceylon, p. 84 .
} 
the labourers. ${ }^{35}$ However, these government efforts remained halfhearted. Many immigrants came to Ceylon on small, privately owned sailing vessels and, thus, neither made use of the newly established infrastructure nor entered into the official statistics.

At no point of the immigration process did the Ceylon Government intervene or offer support. Until very late in the nineteenth century, labour immigration from India to Ceylon remained absolutely freemeaning in that respect free from government control and influence from the very recruiting to the arrival at the Ceylonese estates. However, the relationship between employer and employees once on the estates, their mutual obligations and rights had to be laid down and regulated somehow. Until the enactment of Ordinance 5 of $1841^{36}$ the status, duties and (most of all) the rights of immigrant labourers in Ceylon were legally not clearly defined. This ordinance (and its various amendments) became known as the Master and Servant Laws $^{37}$ and, indeed, in its first draft aimed solely at the regulation of the relationship between an employer and a domestic servant. ${ }^{38}$ But facing a legal vacuum as regards the status of plantation labourers, the version of the ordinance enacted in 1841 was extended to apply to estate labourers as well. The provisions of Ordinance 5 of 1841 were later consolidated and slightly refined with the enactment of Ordinance 11 of $1865 .{ }^{39}$ In short, the Master and Servant Laws regulated the duties of a servant/plantation labourer and identified three actions of such labourers leading to criminal prosecution: neglect of duty (e. g. late attendance, refusal to work etc.) a wide array of 'misconduct' in service (e. g. drunkenness, disobedience, etc.) and the quitting of service without one month's prior notice. ${ }^{40}$ A labourer found guilty of one of these charges was liable to a fine of up to $£_{5}$ or up to three months imprisonment. The only offence on the part of the employer recognised by the Master and Servant Laws was the refusal to pay wages. Furthermore, it is important to note that breaches of

${ }^{35}$ Ibid., p. 85 .

${ }^{36} \mathrm{CO} 5^{6 / 2}$, Ceylon Acts $1841-1843$.

${ }^{37}$ For a further discussion of the Master and Servant Law and its amendments see M. Roberts, "The Master-Servant Laws of 1841 and the 1860 s and Immigrant Labour in Ceylon", Ceylon Journal of Historical and Social Studies, vol. 8, no. 1+2 (1965).

${ }^{38}$ R. Weerakoon, The Evolution of Labour Law in Sri Lanka: Tea Plantation to Free Trade Zone (Colombo: Ceylon Federation of Labour, 1986), pp. $112-13$.

${ }^{39} \mathrm{CO}$ 56/9, Ceylon Acts 1 864-1869.

${ }^{40}$ L. De Mel, The Evolution of Industrial Relations in Ceylon; with Special Reference to Plantations, p. 3 . 
contract under the Master and Servant Laws were deemed criminal offences and thus were speedily dealt with by criminal courts, whereas under Common Law such breaches of contract would have been the subject of civil actions only. ${ }^{41}$

Ordinance 13 of $1889^{42}$ further amended the Master and Servant Laws and clarified two imprecise passages: For the first time a distinction between domestic servants and plantation labourers was made and, secondly, the definition of 'employer' was extended to the current superintendent of an estate, thus solving practical problems frequently arising in the implementation of the laws due to absentee planters. Additionally, the amendment legally recognised the longstanding practice regarding verbal contracts. 'In practice, verbal contract meant the entry of the labourer's name in the estate check-roll and the acceptance by the labourer of the quota of rice issued by the estate as part payment of wages' ${ }^{43}$ This practice now had a legal footing.

From a merely legal viewpoint, the Master and Servant Laws provided both the planter and the labourer with valuable instruments to defend their interests. On the one hand, the planter could easily sue his labourers for breach of contract in various situations as such breaches were broadly (and vaguely) defined. Although Ordinance 11 of 1865 obliged the employer to provide his employees with lodgings, food and medical care during periods of sickness, refusal to pay wages remained the only prosecutable offence on the part of the employer. On the other hand, the Master and Servant Laws recognised the 'free' nature of plantation labour. Although the possibility existed to enter into longer written contracts, almost all labour relations were regulated on the basis of verbal one-month contracts. In theory, the labourer could leave an estate at one month's notice. In times of ever-rising labour demand, this would have placed some power in the hands of the labourers. In reality, a number of customs and practices of plantation recruitment and life kept the bulk of the immigrant labour force from enforcing their rights as laid down in the legislation. The rigid hierarchy of the kangany system and an evolving network of debt bondage served as functional equivalents and secured the availability of a cheap and steady labour force.

We have already briefly discussed how the rising labour demands

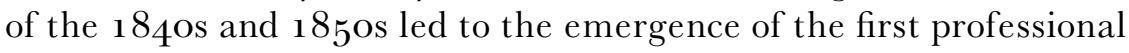

41 Ibid., pp. 2-3.

${ }^{42} \mathrm{CO} 56 / 12$, Ceylon Acts $1885^{-1889}$.

${ }^{43}$ D. Wesumperuma, Indian Immigrant Plantation Workers, p. 26. 
kanganies. Equipped with substantial cash advances those recruiters were sent to the 'coast' - i. e. to South India—to bring back as many new labourers as possible. Originally intended to cover the cost of the kangany's and the labourers' journey, the coast advances soon rose far beyond that in the eye of the steadily growing competition for labour. Vanden Driesen once called the system of coast advances 'the villain of the piece' ${ }^{44}$ Each labourer's share of the coast advance was deducted from his wages in rates. Therefore, the immigrant plantation workers were indebted from the very start of their estate employment. The labourers often owed sums to the planter that they had not even received, as the kanganies tried to keep travel and food costs at a minimum and pocketed the excess money. ${ }^{45}$ This practice also contributed heavily to the high death rates during the immigrants' journey to the estates. Contemporaries estimated that the kanganies spent not even a third of the coast advance and that therefore hundreds of immigrants died of starvation-their bodies being thrown into the sea or left behind at the roadside. ${ }^{46}$

It is important to see that the labourer himself was not directly indebted to the planter. The kanganies occupied an intermediary role in the relation between the planters and the labourers. They owed the total sum given as a coast advance to the planter, and the Indian labourers owed their shares to the kangany. Naturally, this gave the latter a strong hold over the individual labourer, who had already borrowed money to settle his debts in his home village and for the journey before he had even started to work. The kanganies usually charged the labourers with the full sum of the coast advance-even if they had only spent a third or so of the money. Furthermore, the payment of the wages and the issuing of the rice rations were conducted via the kanganies, who by and by became labour supervisors more than workers. Practically, the kangany emerged as the only remaining link between the planter and his workforce.

As the kanganies received a premium for every recruited labourer and later so-called 'head money' for each of their labourers who turned up for work each day ${ }^{47}$, they were interested in recruiting as many new workers as possible. Therefore, '[t] he group became more heterogeneous, often

${ }^{44}$ I. H. Vanden Driesen, Indian Plantation Labour in Sri Lanka: Aspects of the History of

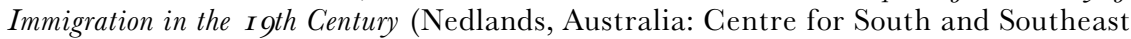
Asian Studies, University of Western Australia, 1982), p. 117.

${ }^{45}$ D. Wesumperuma, Indian Immigrant Plantation Workers, p. 62.

${ }^{46}$ F. Heidemann, Kanganies in Sri Lanka and Malaysia, p. 18.

${ }^{47}$ D. Wesumperuma, Indian Immigrant Plantation Workers, p. 62. 
the labourers hailed from various villages, and in many cases the members had no personal contact before the departure ${ }^{48}$ This weakened the influence of kinship or other social ties among the labourers and the kanganies, and further enhanced the dependence of the recruited on the recruiter. Briefly, the fact that the professional kanganies' income depended on the number of recruited labourers and on their performance on the estate, can be identified as 'the villain of the piece'. Recruitment methods became harsher to maximise the number of immigrants (sometimes even culminating in the kidnapping of villagers or even minors by the kanganies ${ }^{49}$ ) and many labourers were ruthlessly exploited during the journey and their stay at the estate. The kanganies' hold over the labourers' wages and rice ration further aggravated the situation.

Heavily indebted to the kangany, without any social security and receiving money and food only through the kangany's hands, the term 'free labour' loses much of its accuracy. Although every plantation worker was theoretically entitled to quit his employer's service at one month's notice, the informal bondage between the worker and the kangany prevented any such move. For the average labourer, it was almost impossible to repay his debts quickly. Firstly, it had become a common practice among the professional kanganies of the $185^{\mathrm{os}}$ and later to burden the labourers with a much too high initial debt. As a good part of the labourer's wages was issued in kind-namely in rations of one bushel of rice per month for an adult male-only a small margin was paid as balance wages in cash. Dharmapriya Wesumperuma provides us with some figures concerning balance wages and indebtedness in the last quarter of the nineteenth century. According to him, the balance wages of a male worker could amount to anything between 21 and $46 \mathrm{r}$. per year in economically good times. The annual costs of living for an estate worker in the years from 1886 to 1893 lay between 12 and 18.5 r. $^{50}$ This left a margin of 2.5 to $36 \mathrm{r}$. annually out of which the labourer had to repay the debts (with an average coast advance ranging from 10 to $20 \mathrm{r}$.). In these figures no allowance has been made for any cheating or levying of interest on the part of the kanganies. Thus, it becomes clear that the repayment of his full debt might bind a labourer to a kangany for years to come.

While the labourers where bound by debt to their kanganies, the latter owed the sum of the initial coast advance to the planter. During

\footnotetext{
${ }^{48}$ F. Heidemann, Kanganies in Sri Lanka and Malaysia, p. 17.

${ }^{49}$ Ibid., p. 22.

${ }^{50}$ D. Wesumperuma, Indian Immigrant Plantation Workers, p. 211.
} 
the early years of coffee planting, this two-layer relationship gave the planters a strong hold over the labourers. Later, the kanganies benefited both from their increasing margin of profit and from the introduction of the so-called tundu system. With increasing coast advances charged on the labourers' debts but still the same amount really spent, the kangany's net profit steadily rose-and he became less bound to an individual planter. At the same time, the planting community of Ceylon introduced the tundu system to counteract the spreading practice of 'crimping'. So-called 'crimping kanganies' tried to hire deserted labourers (or induced labourers to desert) and sold their labour to the highest bidding planter. As this practice soon proved to be a nuisance to the planters, they introduced the following system: a tundu (meaning a receipt or bill) was issued to the kangany stating his total debt to the planter. Based on the tundu, the future employer had to give an advance to the kangany to settle his old debt, before entering in the new service. 'Crimping kanganies' and their deserted labourers could not produce a tundu and, thus, could not enter into the service of a new employer. ${ }^{51}$ Furthermore, the tundu system helped to keep the regional balance between areas with a surplus of labour and others short of it. However, in the long run, the introduction of the tundu system only strengthened the position of the kangany. In times of labour shortage the tundu system enabled the kanganies to extract advances considerably higher than the tundu debt, and often the labour gangs where transferred from estate to estate. ${ }^{52}$

\section{Government Involvement and the Medical Wants of the Plantation Labourers}

During the heyday of coffee planting in the 1860 os and 1870 os and during the tea boom of the late 1880 os and 1890 os many kanganies made excessive use of their privileges under the tundu system. They consolidated their hold over the labourers, maximised their profits and used times of labour shortage to blackmail the planters and to extract exaggerated advances. Organised in the Planters' Association, the planting community tried its best to counteract this shift of power. The Ceylon Government itself started to get involved in the recruitment and migration process of the Indian labourers only in

${ }^{51}$ F. Heidemann, Kanganies in Sri Lanka and Malaysia, p. 20.

52 D. Wesumperuma, Indian Immigrant Plantation Workers, p. 109. 
the last two decades of the nineteenth century. And only in the early twentieth century, measures were implemented to cut the powers of the kanganies, to counteract debt bondage and to safeguard certain vital interests of the labourers (as well as the planters).

Beyond regulating the status of the labourers and the relationship between employer and employee in the Master and Servant Laws, the Ceylon Government became directly involved in labour politics in the 1880 on only. On 12 th December 1880 the government enacted Ordinance 17 of 1880 , 'The Medical Wants Ordinance', 53 and thereby took over the direct responsibility for much of the health care available to immigrant plantation workers. Until the year 1872 , the planter usually treated a sick labourer himself. Only in severe cases-a decision that the medically unskilled planter had to make-workers were taken to a government civil hospital usually miles and miles away. Doctors in these civil hospitals complained bitterly that in many cases sick immigrants were taken to the hospitals much too late and often little could be done for them anymore. ${ }^{54}$ The planters usually excused this by referring to the immigrants' general dislike of hospital treatment. But the fact that the planters had to pay for the treatment at the government hospital contributed at least as significantly to the late hospitalisation of sick immigrants. Due to the sanitary conditions on the estates and the late hospitalisations, the mortality rate among the immigrant labourers was alarmingly high. Therefore, the Ceylon Government decided in 1872 to organise a new system of health care for the estate population. Ordinance 14 of $1872^{55}$ divided the planting area into districts of manageable size, each with a district hospital under a European medical officer. A District Committee manned by the planters was responsible for the working of the scheme in the district. The cost of this scheme was to be covered by an acreage tax on the estates-the first direct land tax in Ceylon. ${ }^{56}$ With the enactment of Ordinance 14 of 1872 the government placed the responsibility for those new medical facilities on the planting community. The planters naturally resented such direct responsibility and especially the acreage tax. The reluctance on the side of the planters to support the new medical scheme was one

${ }^{53} \mathrm{CO} 56 / 11$, Ceylon Acts $1879-1884$.

${ }^{54}$ M. Roberts, "Indian estate labour in Ceylon during the coffee period, (18301880). Part 2", Indian Economic and Social History Review, vol. 3, no. 2 (1966), 101.

${ }^{55} \mathrm{CO} 56 / 10$, Ceylon Acts $1870-1878$.

${ }^{56}$ D. Wesumperuma, Indian Immigrant Plantation Workers, p. 243. 
factor for its failure. Another one was the enormous influx of Indian immigrants during the years of famine in South India from 1876 to 1878. The additional increase in immigration proved to be beyond the capabilities of the scheme. ${ }^{57}$ Accordingly, the new medical aid scheme collapsed completely, and the Ceylon Government had to step into the breach itself. With the enactment of the Medical Wants Ordinance in 1880 , it took over the responsibility to provide adequate medical facilities to the immigrants. Now the government was in charge of the immigrant hospitals and the medical staff. Like in 1872 , the planting area was divided into districts, each with a district hospital and one or more outdoor dispensaries. Every employer was obliged by law to send a sick labourer to the hospital or-for a fee of $2.5 \mathrm{r}$.- to ask the local medical officer to visit the estate and treat the patient on the spot. The ordinance required every kangany to immediately report cases of sickness to his employer. Furthermore, Superintending Medical Officers were appointed to inspect the sanitary conditions on the estates every half a year. Provisions were made for the registration of births and deaths among the immigrant labourers, and the employer had to supply food and lodging to mothers for a fortnight after the birth of a child. ${ }^{58}$

To finance the new scheme, the Medical Wants Ordinance imposed an export tax not exceeding 20 cents per hundredweight on coffee, cacao and tea and a tax not exceeding 40 cents per hundredweight on cinchona. The income from the tax went into the Medical Aid Fund. ${ }^{59}$ The planting community vigorously opposed the implementation of the Medical Wants Ordinance. Especially, the planters despised the introduction of an export duty on plantation crops, as they were of the opinion that the government had to finance the Medical Aid scheme out of the general revenue. And if it should really be found that a new tax was necessary for the financial realisation of the scheme, the planters pointed out, the import duty on rice should be increased. ${ }^{60}$ In that case, the planters would have been able to pass the burden of the increased duty on to their labourers.

The Planters' Association petitioned hard against the confirmation of Ordinance 17 of $1880^{61}$ —and found an ally in the Colonial Office.

${ }^{57}$ M. Roberts, "Indian estate labour in Ceylon", pp. 103-04.

${ }^{58}$ D. Wesumperuma, Indian Immigrant Plantation Workers, p. 253.

${ }^{59} \mathrm{CO}$ 56/1 1, Ceylon Acts 1879-1884.

${ }^{60}$ M. Roberts, "Indian estate labour in Ceylon", p. 106.

${ }^{61} \mathrm{CO} 54 / 532,5^{\text {th }}$ March $1881 /$ No. 12 , Douglas to Kimberley. Enclosure. 
Whitehall opposed an export duty on plantation crops and proposed a capitation tax on the number of employed immigrant labourers on each estate. The provisions of the Medical Wants Ordinance as regards the medical facilities were not altered, but according to the wishes of the Colonial Office, Ordinance 18 of 1881 was passed to amend the Medical Wants Ordinance and replaced the export duty with an annual tax on the number of immigrant employees. ${ }^{62}$ Later, the Ceylon Government found that the capitation tax was impracticable under the persisting circumstances and the amending Ordinance of 1881 was repealed. Ordinance 9 of 1882 abolished the capitation tax and reinstated the export duty on plantation crops to finance the scheme. Nevertheless, the government paid tribute to the constant complaints of the planters and lowered the duty to a maximum of 10 cents per hundredweight on tea, coffee and cacao and a maximum of 20 cents on cinchona. ${ }^{63}$ The government carried approximately three-fourths of the total cost of the scheme, whereas the planters contributed a mere quarter.

The first report on the working of the scheme gave detailed figures on the cost of the Medical Aid system. The total expenditure amounted to $134,032.05 \mathrm{r}$. in 1883 . Of that sum 30,02 1.33 r. were recovered from the planters under the provisions of the Medical Wants Ordinance, thus leaving a sum of $104,010.72$ r. to be paid by the government. ${ }^{64}$ The unchanged mortality rate among the immigrants and the great expenditure involved were the main drawbacks of the new scheme in the eyes of the government. In the district hospitals, the death rate still amounted to $19.84 \%$ of all hospitalised persons. ${ }^{65}$

Throughout the 1880 os, the death rate among the coolies as well as the general sanitary state of the estates did not improve on any significant scale. Although the available medical facilities had been multiplied, and hospitals and dispensaries had been erected, the late hospitalisation of the sick labourers as the main problem remained. Reference has already been made to the alleged reluctance of the labourers to go to hospital. It was the prevailing opinion among planters and administrators alike that the sick cooly himself delayed his hospitalisation as long as possible in order to stay with his family and friends. Contemporary remarks on the subject—even from critical

${ }^{62} \mathrm{CO} 56 / 11$, Ceylon Acts $1879-1884$.

${ }^{63} \mathrm{CO} 56 / 11$, Ceylon Acts $1879-1884$.

${ }^{64} \mathrm{CO} 54 / 554$, 9th July $1884 /$ No. 259, Gordon to Derby.

${ }^{65} \mathrm{CO} 54 / 554,9$ th July $1884 /$ No. 259, Gordon to Derby. Enclosure. 
men like Principal Civil Medical Officer Kynsey-mostly neglect the determining influence of the employer and the kangany on the labourer. Not only depended the kangany's 'head money' on the number of labourers turning up for work each day, he often also feared that the sick labourer could run away when he was not under the kangany's direct control-e.g. in hospital. ${ }^{66}$ Therefore, many kanganies did not report cases of sickness among the labourers and prevented or delayed treatment or hospitalisation. The planter himself-if the kangany informed him about cases of sickness-was similarly reluctant to treat the cooly, because this inflicted additional costs on him.

In 1893, Governor Havelock finally appointed a commission to investigate the deficiencies of the prevailing Medical Aid system and to suggest possible remedies. The commission proposed the creation of estate dispensaries to facilitate the medical treatment of sick labourers. The planting community first resisted this proposal, but later agreed to it and cooperated in the establishment of estate dispensaries. The new prosperity of tea cultivation and the rising demand for labour considerably influenced the planters in that decision. By 1900, 103 estate dispensaries had been created. ${ }^{67}$ Although the commission's assumption that '[i]t is the interest of the Employers to keep their labourers in good health ${ }^{68}$ proved to be correct during times of labour shortage, the cooperation of the kanganies did not improve. The estate dispensaries were frequently used, but in the district hospitals the death rate among the immigrants remained at the same high level. ${ }^{69}$ This stagnation can mostly be attributed to the prevalence of the kangany system and the kanganies' keenness on the 'head money'.

Although the Medical Wants Ordinance was not successful in reducing the high mortality rate among immigrant labourers and only partially bettered the medical treatment offered to sick workers, its enactment is a landmark in the history of nineteenth-century labour policy in Ceylon. For the first time, the Ceylon Government became directly involved in matters of immigrant labour and took over responsibility itself. Hitherto, the government had restricted itself to the issuance of a vague and at times distorted legal basis regulating labour contracts. Now, government officials were appointed to control

${ }^{66}$ D. Wesumperuma, Indian Immigrant Plantation Workers, p. 257.

${ }^{67}$ Ibid., p. 275 .

${ }^{68} \mathrm{CO} 54 / 610,5^{\text {th }}$ November $1893 /$ No. 378 , Havelock to Ripon.

69 D. Wesumperuma, Indian Immigrant Plantation Workers, p. 273. 
TABLE 2

The Ceylon Coffee Industry, I865-86(Annual Figures and Annual Averages)

\begin{tabular}{llcll}
\hline Year & $\begin{array}{l}\text { Export volume } \\
\text { (in ooo cwt.) }\end{array}$ & $\begin{array}{l}\text { Export unit } \\
\text { value (in s./cwt.) }\end{array}$ & $\begin{array}{l}\text { Area planted } \\
\text { (in ooo acres) }\end{array}$ & $\begin{array}{l}\text { Yield (in } \\
\text { cwt./acre) }\end{array}$ \\
\hline $1865-69$ & 939 & 52 & 243 & $3 \cdot 9$ \\
$1870-74$ & 881 & 66 & 276 & $3 \cdot 2$ \\
$1875-79$ & 795 & 108 & 310 & 2.6 \\
$1880-84$ & 433 & 89 & 259 & 1.7 \\
1885 & 316 & 78 & 139 & 2.3 \\
1886 & 179 & 89 & 110 & 1.6 \\
\hline
\end{tabular}

Source: Snodgrass (1966): 20.

the implementation of the new law. So, almost half a century after the introduction of the indenture system, 'free' labour migration finally experienced some government control as well.

\section{Tea, Tin Tickets and the Ceylon Labour Commission}

In the closing years of the 1870 , the coffee industry of Ceylon saw the beginning of its end. The total ruin of the island's coffee plantations within only a couple of years is such a prototypical example for the hazards of monoculture that its story has been told over and over again by planters, officials and historians alike. Here, it suffices to say that a leaf fungus-later mostly called the Coffee Leaf Diseasevirtually wiped out Ceylon's coffee plantations in the late 1870 ond early 1880 s (see the decline in coffee acreage and exports in Table 2 ). Although the planters tried to squeeze the last bit of sellable coffee out of their holdings, the coffee planting enterprise was practically dead by 1885 . The prevalence of coffee monoculture in Ceylon had favoured the wildfire-like spread of the disease in the first place. And now the collapse of the island's sole economic backbone drew the whole crown colony in a financial crisis of unforeseen extent. Only with the capital derived from cinchona cultivation and the efforts put into the cultivation of tea was this depression finally overcome. By the end of the 1880 s, the earlier experiments with tea cultivation had proved profitable and finally re-introduced economic prosperity to the island with the establishment of yet another monoculture (see Table 3 for the growth of tea cultivation since 1880 ).

The tea boom of the late 1880 os and 1890 s dwarfed the 'coffeemania' of earlier decades and has only been possible due to the prior 
TABLE 3

Tea: Acreage and Exports, I $880-90$

\begin{tabular}{lrrr}
\hline Year & Acreage & \multicolumn{1}{c}{$\begin{array}{l}\text { Export volume } \\
(\mathrm{lbs})\end{array}$} & \multicolumn{1}{c}{$\begin{array}{l}\text { Export value } \\
(\mathrm{Rs})\end{array}$} \\
\hline 1880 & 14,266 & 162,576 & $15^{\mathrm{O}, 641}$ \\
1881 & $14,35^{\circ}$ & 348,573 & 322,993 \\
1882 & $12,4^{\circ}$ & 697,268 & 591,806 \\
1883 & 19,797 & $1,665,768$ & 916,172 \\
1884 & 57,626 & $2,392,973$ & $1,435,784$ \\
1885 & 120,808 & $4,372,722$ & $2,842,269$ \\
1886 & 164,758 & $7,849,888$ & $5,102,427$ \\
1887 & 199,647 & $13,834,057$ & $8,300,434$ \\
1888 & 231,601 & $23,820,472$ & $12,624,850$ \\
1889 & 207,413 & $34,345,85^{2}$ & $17,859,843$ \\
1890 & 235,794 & $45,799,519$ & $22,899,759$ \\
\hline
\end{tabular}

Source: Ceylon Statistical Blue Books 1880-9o.

existence of a plantation infrastructure in Ceylon. The labour demand of the tea estates steadily increased: firstly, tea cultivation required more labour per acre than coffee cultivation; ${ }^{70}$ and secondly, tea is harvested year-round, whereas coffee has a single harvest season (October to February in the case of Ceylon). ${ }^{71}$ Such rising labour demands now often placed the planters at the mercy of their kanganies who took full advantage of the blessings of the tundu system. The capital-intensive tea industry had led to the gradual disappearance of

${ }^{70}$ R. Wenzlhuemer, "The Sinhalese contribution to estate labour in Ceylon, $1881-$ 1891 ", p. 450. L. A. Wickremeratne, "The establishment of the tea industry in Ceylon. The first phase, C 1870 to C 1900", Ceylon Journal of Historical and Social Studies (new series), vol. 2, no. 2 (1972), 142.

${ }^{71}$ The missing seasonal pattern of labour demand has often been identified as one of the major changes in labour immigration to Geylon brought about by tea cultivation. Again, it is Patrick Peebles who now challenges this view: in his 'Plantation Tamils of Ceylon' he tries to do away with the 'myth of seasonal labour'. He suggests that the coffee planters were interested in the maintenance of a large enough residential (i.e. nonseasonal) labour force on their estate also outside the time of the coffee harvest. Consequently, Peebles attributes the "discourse about seasonal labour" to a certain 'construction of knowledge about Plantation Tamils'. In the end, figures and tables presented by Peebles himself illustrate the partly seasonal character of labour migration during coffee times. Although he attributes the time of migration to the monsoon rather than to the coffee harvest, Peebles cannot explain the seasonal pattern of immigration and emigration he himself depicts in Figure 4.1. Thus, labour immigration to the coffee estate has been seasonal to a certain extent-with a growing resident labour force present on the estates year-round. With the advent of tea cultivation this seasonal pattern faded as tea required the same attendance throughout the year. P. Peebles, The Plantation Tamils of Ceylon, pp. 81-83. 
the traditional proprietor-planter and to the emergence of estates run by joint-stock tea companies. The close relationship many planters had entertained with their head kanganies could rarely be upheld with frequently changing superintendents in charge of the estates. ${ }^{72}$ Thus, many kanganies felt less bound to their estates and made full use of debt bondage and tundus. The increasing powers of the kangany urged the planters (and later the Ceylon Government) to reform the system of recruitment, transhipment and supervision of Indian labourers. In 1892, the planting community first tried to cut the coast advances given to the kanganies by introducing a system of through-booking for Indian immigrants. In cooperation with the South Indian Railway, the British India Steam Navigation Company and the Geylon Government Railway the planters tried to pre-organise their future labourers' journey to Ceylon and issued a part of the coast advances in railway and steamer tickets. ${ }^{73}$ Unfortunately, this system had little official backing and proved to be inefficient. Only when the Ceylon Government joined a similar scheme in 1901-the so-called 'tin ticket' system-a first significant step was made to restrict the powers of the kangany. The Ceylon Government started to issue tin tokens with a letter and number stencilled on it referring to the estate hiring a labourer. Estate superintendents bought these tickets from the government and issued them to their kanganies who in turn took them to India and distributed the tin tickets to the newly recruited labourers. The holder of such a ticket immigrated to Ceylon with the support and under the control of the Ceylon Government and was directly dispatched by steamer and railway to the estate stencilled on his ticket. This seriously limited the influence of the kanganies and-for the first time-brought labour immigration at least partially under government supervision. ${ }^{74}$ Unfortunately, it did not significantly decrease the financial burden of the labourers as the cost of the tin ticket was later added to their initial debt.

Although the tin tickets proved to be a considerable success, the planters and the government adopted further measures to supervise labour recruitment and immigration. In 1904, the Ceylon Labour Commission (CLC) was founded. The Ceylon Government gave the commission official recognition and financed one-fourth of the total

\footnotetext{
${ }^{72}$ D. Wesumperuma, Indian Immigrant Plantation Workers, pp. $65^{-66 .}$

${ }^{73}$ Ibid., p. 55 .

${ }^{74}$ Ibid., pp. 68-69.
} 
annual cost of the commission with a government grant. ${ }^{75}$ The Ceylon Labour Commission had several agencies in South India and supervised the kanganies' work there. The CLC organised and financed necessary cash advances, monitored the recruitment process and issued tin tickets in South India. ${ }^{76}$ This meant that finally the recruiting kanganies had come under closer control of the planters and the government. Little space was left to overcharge the labourers on their travel costs or to withhold money due to them. The efforts of the Planters' Association and direct government intervention reduced the abuses of coast advances and tundus on the part of the kanganies. Nevertheless, the situation of the labourers improved only gradually. The travel cost was still added to their initial debt and rice and balance wages were still incredibly low. This is altogether not surprising as it had never been the goal of government (nor the planters') intervention to better the situation of the immigrant labourers. Instead, 'the aim of the CLC was to get labor cheaper'. ${ }^{77}$

\section{Conclusion}

During most of the nineteenth century, the labour policy of the Ceylon Government limited itself to the regulation of the legal status of the immigrant labourers and of the terms of contract between employers and employees. The legislative complex known as the Master and Servant Laws on the one hand favoured the planting community by making a wide array of contract breaches on the part of the labourers subject to criminal prosecution. On the other hand, it officially recognised and regulated the practice of self-renewing onemonth verbal contracts between the planter and the labourer which could (theoretically) be terminated at one month's notice. Considering the large and steadily increasing labour demand of the plantations this practice would normally have been beneficial for the labourers by improving their bargaining position. But such effects of the law were counteracted by the emergence of the kangany system of labour recruitment and supervision that, instead of a proper government labour policy, regulated the influx of immigrant labourers as well as their working and living conditions. Practically from the time of

${ }^{75}$ Ibid., pp. 69-70.

${ }^{76}$ P. Peebles, The Plantation Tamils of Ceylon, p. 65.

${ }^{77}$ Ibid. 
recruitment in India, the labourers were indebted to the planters (or later the kanganies) and were thus bound to the plantations. Although almost all labourers only entered into one-month verbal contracts, high initial debt, marginal balance wages and their dependence on the kangany usually prevented the termination of an engagement at short notice. In reality, many immigrant labourers were as tightly attached to their plantations as their West Indian or Mauritian counterparts under the indenture system. In the absence of any direct government intervention in labour issues, the kangany and tundu systems acted as functional equivalents securing a steady influx of immigrant labour, organising the recruitment and transhipment of the labourers and regulating much of the labourers' work and life on the plantations. Only in the year 1880 the Geylon Government became directly involved in immigrant labour policy through the enactment of the Medical Wants Ordinance. For the first time, the government took over direct responsibility for the medical treatment of the immigrant labourers thus paying tribute to the enormously high death rate among plantation workers. Twenty years later, the Ceylon Government finally started to monitor and support labour recruitment and transhipment directly. It cooperated with the Ceylon Planters' Association and inaugurated the tin ticket system in 1901 and the Ceylon Labour Commission in 1904. These two occasions mark the beginning of real government involvement in immigration matters-although it took the Indian and the Ceylon Government 19 more years to bring about more far-reaching changes in the system that would be positively felt by the immigrant labourers themselves. ${ }^{78}$

\section{Sources and Literature}

Public Record Office: CO 54, Original Correspondence. Vol. CO 54/524-CO 54/668. Public Record Office: $\mathrm{CO}_{5} 6$, Ceylon Acts. Vol. CO 56/2-CO 56/1 2.

Public Record Office: CO 59, Statistical Blue Books. 1880-19oo.

A. Bandarage, Colonialism in Sri Lanka: The Political Economy of the Kandyan Highlands, I833-I 886. Vol. 39, New Babylon, Studies in the Social Sciences. (Berlin; New York: Mouton, 1983).

N. Dawood, Tea and Poverty: Plantations and the Political Economy of Sri Lanka. (Kowloon, Hong Kong: Urban Rural Mission, Christian Conference of Asia, 1980).

L. De Mel, The Evolution of Industrial Relations in Ceylon; with Special Reference to Plantations, International Educational Materials Exchange, 3026. (Geneva: International Institute for Labour Studies, 1972).

${ }^{78}$ D. Wesumperuma, Indian Immigrant Plantation Workers, p. $4^{1}$. 
C. R. De Silva, Ceylon under the British Occupation, I795-1833. (Colombo: Colombo Apothecaries, 1953).

K. M. De Silva, 'Indian Immigration to Ceylon: The First Phase C. 1840-1855', Ceylon Journal of Historical and Social Studies, vol. 4 (1961), 106-37.

K. M. De Silva, Social Policy and Missionary Organizations in Ceylon, I 840-I 855. (London: Longmans, 1965).

F. Heidemann, Kanganies in Sri Lanka and Malaysia: Tamil Recruiter-Cum-Foreman as a Sociological Category in the Nineteenth and Twentieth Century, Ganesha; 5. (Muenchen: Anacon, 1992).

O. Hollup, Bonded Labour: Caste and Cultural Identity among Tamil Plantation Workers in Sri Lanka. (New Delhi: Sterling Publishers, 1994).

N. Kuruppu, 'A History of the Working-Class Movement in Ceylon. 1. Labour and the Rise of Capitalism', Ceylon Historical Journal, vol. 1, no. 2 (1951), 129-46.

F. Lewis, Sixty-Four Years in Ceylon: Reminiscences of Life and Adventure. (Colombo: Colombo Apothecaries, 1926).

W. A. Lewis, 'The Export Stimulus', in W. A. Lewis (ed.), Tropical Development, $1880-$ 1913 (Evanston: Northwestern University Press, 1970), pp. 13-45.

P. Peebles, The Plantation Tamils of Ceylon, New Historical Perspectives on Migration. (London; New York: Leicester University Press, 2001).

P. Peebles, Social Change in Nineteenth Century Ceylon. (New Delhi: Navrang in collaboration with Lake House Bookshop, Colombo, 1995).

M. Roberts, 'Indian Estate Labour in Ceylon During the Coffee Period, (1830-1880). Part 1', Indian Economic and Social History Review, vol. 3, no. 1 (1966), 1-52.

M. Roberts, 'Indian Estate Labour in Ceylon During the Coffee Period, (1830-1880). Part 2', Indian Economic and Social History Review, vol. 3, no. 2 (1966), 101-36.

M. Roberts, 'The Master-Servant Laws of 1841 and the 1860 s and Immigrant Labour in Ceylon', Ceylon Journal of Historical and Social Studies, vol. 8, no. 1+2 (1965), 2437 .

M. Roberts, and L. A. Wickremeratne, 'Export Agriculture in the Nineteenth Century', in K. M. De Silva (ed.), University of Ceylon History of Ceylon. From the Beginning of the Nineteenth Century to 1948 (Peradeniya: University of Peradeniya, 1973), pp. 89-118.

V. Samaraweera, 'Economic and Social Developments under the British, 1796-1832', in K. M. De Silva, (ed.), University of Ceylon History of Ceylon. From the Beginning of the Nineteenth Century to 1948 (Peradeniya: University of Peradeniya, 1973), pp. $48-65$.

A. Satyanarayana, Birds of Passage. Migration of South Indian Labour Communities to SouthEast Asia, I9-2oth Centuries, A.D., Clara Working Paper I I. Amsterdam, 2001.

D. R. Snodgrass, Ceylon; an Export Economy in Transition. (Homewood, Illinois: R. D. Irwin, 1966).

H. R. Tinker, A New System of Slavery. The Export of Indian Labour Overseas, I830-1920. (London: Oxford University Press, for the Institute of Race Relations, 1974).

I. H. Vanden Driesen, Indian Plantation Labour in Sri Lanka: Aspects of the History of Immigration in the I gth Century. (Nedlands, Australia: Centre for South and Southeast Asian Studies, University of Western Australia, 1982).

I. H. Vanden Driesen, 'Some Aspects of the Financing of Commercial Enterprise in $19^{\text {th }}$ Century Ceylon', Ceylon University Review, vol. 18, no. 3+4 (1960), $213^{-21}$.

I. H. Vanden Driesen, 'Some Trends in the Economic History of Ceylon in the 'Modern' Period', Ceylon Journal of Historical and Social Studies, vol. 3, no. 1 (1960), 1-1 7 .

J. L. A. Webb, Tropical Pioneers: Human Agency and Ecological Change in the Highlands of Sri Lanka, I 80o-I9oo, Ohio University Press Series in Ecology and History. (Athens, Ohio: Ohio University Press, 2002).

R. Weerakoon, The Evolution of Labour Law in Sri Lanka: Tea Plantation to Free Trade Zone. (Colombo: Ceylon Federation of Labour, 1986). 
R. Wenzlhuemer, 'The Sinhalese Contribution to Estate Labour in Ceylon, 18811891', Journal of the Economic and Social History of the Orient, vol. 48, no. 3 (2005), $44^{2}-5^{8}$.

D. Wesumperuma, Indian Immigrant Plantation Workers in Sri Lanka: A Historical Perspective, I880-1910. (Nugegoda: Dharmapriya Wesumperuma, 1986).

D. W. A. Wickramasinghe, and D. C. Cameron, 'British Capital, Ceylonese Land, Indian Labour: The Imperialism and Colonialism of Evolution of Tea Plantations in Sri Lanka', Paper presented at the Critical Management Studies Conference (Management and Organizational History), Cambridge, 4-6 July 2005.

L. A. Wickremeratne, 'The Establishment of the Tea Industry in Ceylon. The First Phase, C 1870 to C 1900', Ceylon Journal of Historical and Social Studies (new series), vol. 2, no. 2 (1972), 131-55. 